\title{
Critical review on PPP Research - A search from the Chinese and International Journals
}

\author{
Shang Zhang, Albert P.C. Chan, Yingbin Feng, Hongxia Duan, Yongjian Ke
}

\begin{abstract}
A significant number of literatures have concentrated on diverse issues related to PublicPrivate Partnership (PPP) both in China and abroad. However, there is no systematic analysis on the PPP research progress and status in Chinese journals, which is worth investigating because China is one of the largest PPP markets globally. In addition, there are many PPP publications in international journals based on the context of China. A comparative study is still missing between the PPP publications in Chinese journals and international journals. This paper hence aims to conduct a critical review of PPP publications from selected first tier Chinese journals and international journals. Based on a three-stage literature review research framework, 615 and 70 high quality research papers on PPP topics were selected from Chinese and international journals in the last decade between 2005 and 2014, respectively. Main research methods, research topics and research findings were then identified through content analysis and statistical analysis methods. It is found that in these two journals the frequently adopted research methods are case study, literature review, modelling, questionnaire survey and comparison; and the popular research topics include PPP models and their application, risk management, financing and economic issues, legal and procurement issues, government regulation and guarantee. Comparison analysis results show that in terms of order of popularity, there are more similarities in the research topics than research methods in Chinese and international journals. The outcomes of this paper contribute to the PPP body of knowledge through summarizing PPP research in Chinese journals and international journals in the context of China. In addition, the findings are valuable for Chinese researchers to embark future research on PPP. This paper also breaks the language barrier and enriches western researchers a better understanding of the research status of PPP in the context of China.
\end{abstract}

Keywords: Public-private partnership; Review; Chinese journals; International journals; Research; China

\section{Introduction}

Public-private partnership refers to a particular procurement approach in which the projects are executed with a broader span of contractual relationships between public and private entities to provide a service and/or an asset (Tang et al., 2013). PPP model is popular in constructing infrastructure projects, (e.g. highways, tunnels, bridges, etc.), as these projects usually need a huge investment which is a heavy financial burden for most of the governments, especially in developing countries. There are also other motivations to initiate PPP projects, e.g. improving efficiency and

Copyright: International Journal of Project Management 2016. (C) 2016 Shang Zhang, Albert P.C. Chan, Yingbin Feng, Hongxia Duan, Yongjian Ke. This is an Open Access article distributed under the terms of the Creative Commons Attribution 4.0 Unported (CC BY 4.0) License (https://creativecommons.org/licenses/by/4.0/), allowing third parties to copy and redistribute the material in any medium or format and to remix, transform, and build upon the material for any purpose, even commercially, provided the original work is properly cited and states its license.

Citation: Zhang, S., Chan, A. P. C., Feng, Y., Duan, H., \& Ke, Y. (2016). Critical review on PPP Research - A search from the Chinese and International Journals. International Journal of Project Management, 34(4), 597-612. doi: 10.1016/j.ijproman.2016.02.008

Corresponding author: Shang Zhang; Email - zhangshfan@163.com 
performance of the project, using the technology and skills from the private entities (Public-Private Infrastructure Advisory Facility, 2007), innovation in providing the public services, time and cost reduction in delivering the project, sharing risks with private entities (Li et al., 2005), etc. Both developing and developed countries have been actively inviting private entities to participate in constructing their infrastructure projects (Tserng et al., 2012).

PPP has also been attractive to the industry, government and academia in the last decade in China, and the development of PPP models can be briefly divided into three stages: (1) from mid-1980s to end of 1990s, (2) from early 2000s to 2010s (Cheng and Wang, 2009), and (3) from 2013 to present.

Shenzhen Shajiao B Power Plant, constructed in middle of 1980s using Build-Operate-Transfer (BOT) delivery method, is the starting point of PPP history in modern construction industry in China (Hu et al., 2011). However, this project has no significant impact on popularizing the PPP model. Until middle of 1990s, the first PPP development wave emerged and power plants represented the largest PPP market share. The typical BOT project in this period is Laibin B power plant in Guangxi Province (Hu et al., 2011). But, due to inexperience of project participants, immature legal systems, and improper risk allocation strategies between public and private entities, many PPP projects faced difficulties in implementing the contract and/or resulted in conflicts, renegotiation or failure. To illustrate the phenomenon, some researchers in China name BOT projects in this stage as BOT Trap (Hu et al., 2011). At the end of this stage, the central government decided to clean up the illegal projects, which led to a fadeout of the first round of private investment (Ke et al., 2011).

Improvements were achieved in the second surge of PPP development. Based on the lessons learned at the first stage and from the best practices of managing PPP projects in other countries, more PPP projects were successfully constructed and operated. PPP projects at this stage covered a variety of nature, including highways, subways, sport facilities, ports, power plants, etc. The famous Beijing Olympic Sport Stadium, started construction in 2002, is one of the sample PPP projects in this period (Hu et al., 2011). Other typical PPP projects at this stage include the Nanjing Yangtse River Third Bridge (BOT model) (Chen and Xu, 2006), the Beijing Subway Olympic Line (the first BuildTransfer (BT) infrastructure project in China), the Shenzhen Subway Line 5 (the largest BT infrastructure project in China) (Yan and Cui, 2011), to name a few.

In 2013, the Third Plenary Session of the 18th Central Committee of the Communist Party of China was held, in which privatization of the infrastructure construction and operation was highlighted again to alleviate the huge finance burden in the fast urbanization process in China. In fact, the meeting has become a new turning point for the PPP development in China. During the meeting, Ministry of Finance (MoF) was selected as the responsible unit by the central government to supervise and regulate the privatization of public infrastructure development with special focus on ensuring the finance feasibility (including Value for Money) and success of PPP project. In 2014 and 2015, MoF and National Development and Reform Commission (NDRC) issued several important guidance documents (see Table 1 for details) to accelerate and regulate the development of PPP model in China (Nanfangweekend, 2015). 
Table 1

Important guidance documents issued by MoF and NDRC in 2014 and 2015.

\begin{tabular}{|c|c|c|c|}
\hline Time & Issuance body & Name of document & Note \\
\hline December 4th, 2014 & MoF & PPP Model Implementation Guidance (trial edition) & $\begin{array}{l}\text { Specify the guidance for the PPP project identification, } \\
\text { preparation, procurement, execution and transfer. }\end{array}$ \\
\hline December 4th, 2014 & NDRC & PPP Implementation Guidance & $\begin{array}{l}\text { Request regional Development and Reform Commission } \\
\text { to report PPP project to NDRC to establish a central } \\
\text { database. }\end{array}$ \\
\hline December 4th, 2014 & NDRC & PPP Project General Contract Guidance (2014 edition) & As a PPP standard conditions of contract for reference. \\
\hline January 20th, 2015 & MoF & $\begin{array}{l}\text { Notice of Regulating Contract Management Issue in PPP } \\
\text { Project }\end{array}$ & Specify the contract management issue in PPP project. \\
\hline January 20th, 2015 & MoF & PPP Project Contract Guidance & As a PPP standard conditions of contract for reference. \\
\hline January 20th, 2015 & NDRC & $\begin{array}{l}\text { Collect public opinion about the Regulation on } \\
\text { Concession Operation Management of Infrastructure } \\
\text { and Public Utility }\end{array}$ & $\begin{array}{l}\text { Specify the concession operation management of PPP } \\
\text { project. }\end{array}$ \\
\hline April 14th, 2015 & MoF & $\begin{array}{l}\text { Guidance for Evaluation of PPP Project Finance Bearing } \\
\text { Capacity }\end{array}$ & $\begin{array}{l}\text { Specify two finance evaluation criteria of PPP project } \\
\text { implementation. }\end{array}$ \\
\hline
\end{tabular}

From 1990 to 2011, China has developed the largest number of projects with the involvement of private entities among developing countries (World Bank, 2013), and the strong promotion of PPP model from the central government since 2013 has also stimulated a wider application in China. However, when comparing with the developed countries, the PPP approach is still considered immature in China, even PPP concept has been adopted for more than 30 years since the first BOT project (Chan et al., 2011).

The extensive practices of the PPP models in China have also greatly promoted the research on successful management of PPP projects in the last decade. Due to the unique economic, environmental, legal, cultural and political background, PPP has its country-specific features and application formats/procedures in China compared with other countries. In addition, considering the large amount of PPP projects completed, undergoing, being planned and even greater potential in the future, the development experience of PPP models in China is valuable both for China and other countries to improve the performance of initiating new PPP projects. From this point of view, PPP research in the context of China shall be an integral and critical part of the overall global PPP body of knowledge.

In recent years, several international publications have specifically focused on reviewing particular research themes in the Construction Management field, such as Ke et al. (2009) in summarizing the PPP research progress, Yi and Chan (2014) in reviewing labor productivity, and Le et al. (2014) in analysing the corruption issue. However, there is no such systematic analysis on the PPP research progress in the context of China. The existing Chinese literature review articles only focused on a specific PPP research field with qualitative methods, such as concession period decision method (Wang et al., 2009), real option evaluation method (Liu et al., 2010), risk allocation (Du and Yin, 2011), project governance (S.B. Zhang et al., 2014), trust (Du and Wang, 2012), etc. A quantitative analysis of PPP research status in Chinese Journals is not available at the moment. Furthermore, given that there are also many PPP publications in International Journals with a focus on China, a comparative study on the research status in Chinese and International Journals is interesting but still missing. Therefore, quantitatively mapping the overall PPP research structure will not only benefit Chinese researchers to embark future research on PPP, but also enrich western practitioners and academics to better understand PPP research status in the context of China. This paper attempts to fill this knowledge gap and aims to answer the following five questions:

1) What is the development status of PPP research in Chinese and International Journals on chronological basis?

2) What research methods are frequently adopted by PPP researchers in the last decade? Are there any changes in the methods adopted in the ten-year period? 
3) What topics are the focuses of PPP research in Chinese and International Journals? Is there any shift in the research interests in the ten-year period?

4) What types of projects are the popular target projects in PPP research in the last decade?

5) What are the similarities and differences in Chinese and International Journals in terms of research methods adopted and research topics in PPP in the ten-year period?

This paper is organized as the following: In Section 2, the research method of this study, specifically the data collection from the papers in Chinese and International Journals and data analysis process, are illustrated. In Section 3, the chronology of PPP papers in Chinese and International Journals are presented. In Section 4, research methods adopted by PPP researchers in both groups of Journals are analysed. In Section 5, research topics of these PPP papers in both Journals are statistically studied and main research topics are critically reviewed. In Section 6 , the nature of projects studied in the PPP papers are summarized. In Sections 7 and 8, main conclusions as well as limitations and future research directions are presented.

\section{Research methods}

In order to achieve the above research objectives, a research framework similar to Ke et al. (2009) in reviewing PPP research status and Yi and Chan (2014) in reviewing labour productivity study, was adopted as shown in Fig. 1.

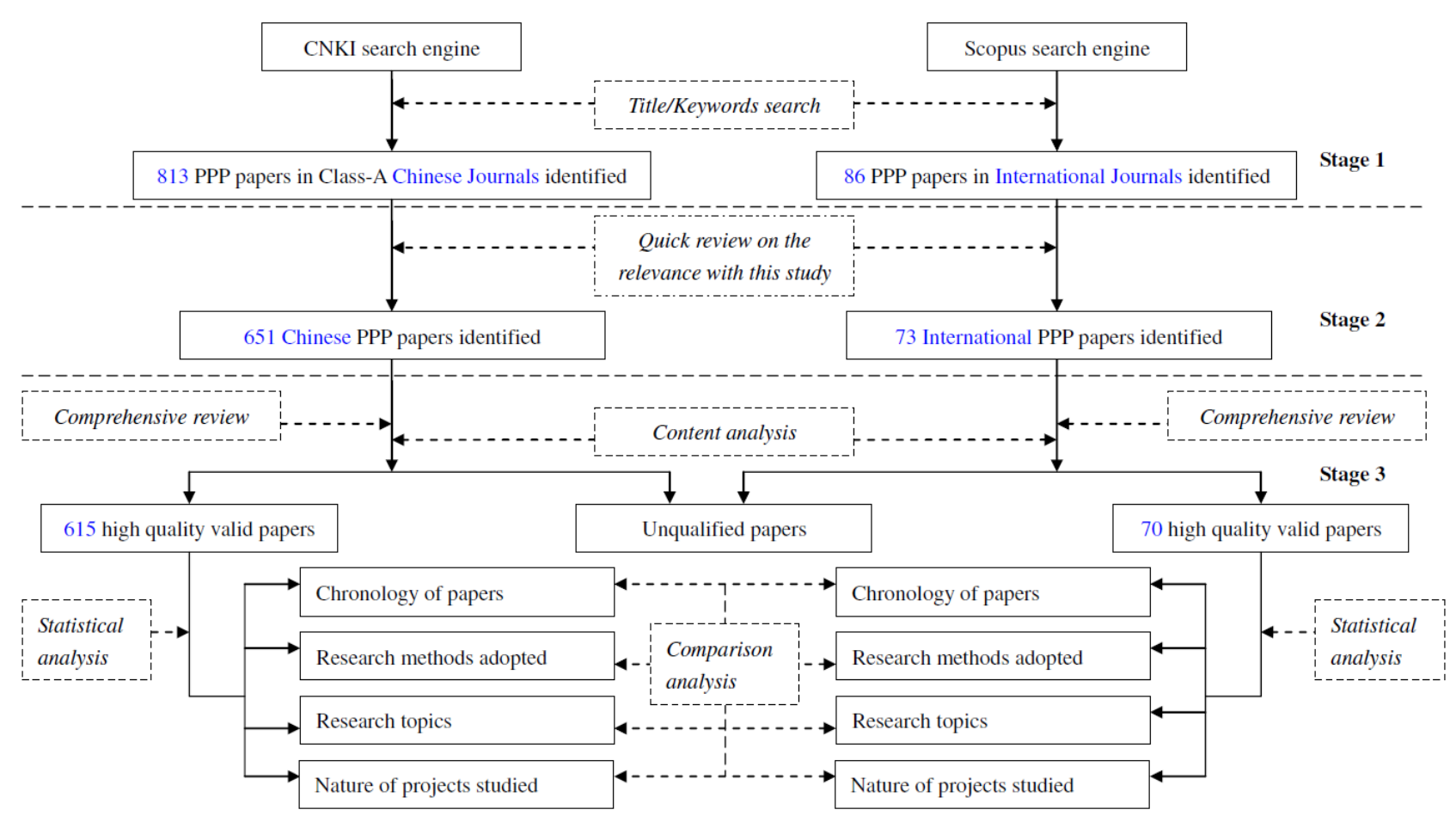

Fig. 1. Research framework for this study (adapted from Ke et al. (2009) and Yi and Chan (2014)) Note: 1. For Chinese PPP papers, the search title/keyword also includes its compatible meaning in Chinese, e.g. Gongsi Heying, Gongsi Hezuo, and Gongsi Huoban Guanxi. 2. Since the Class-A Chinese journals (well-known first-tier Chinese journals recommended by Peking University Library) list has been updated every three-four years. But the Chinese CNKI data base does not change accordingly. Therefore, a particular journal was considered as Class-A journal as long as it is in the list of first-tier Chinese journals at least one time in the last decade. 
As addressed by Ke et al. (2009) and Gurgun and Touran (2014), there is a wide range of variations in PPP family, including PPP, Private Finance Initiative (PFI), BOT, BT, Transfer-Operate-Transfer (TOT), Build-Own-Operate-Transfer (BOOT), etc. Therefore, a critical review on PPP research should include these variations. On the basis of this condition, the research framework comprises the following three stages:

1) Stage 1: For Chinese Journals, PPP/PFI/BOT/BT/TOT/BOOT were used as the search keywords to identify journal papers published from 2005 to 2014 through CNKI database, which is the most comprehensive data base of research publications in China. In order to ensure the quality of publications, the papers were selected from Class-A journals (well-known first-tier Chinese journals recommended by Peking University Library) in China. Approximately 813 PPP Chinese Journal papers were collected in October 2015 at this stage. For International Journals, a search was conducted using PPP/PFI/BOT/BT/TOT/BOOT as the search keywords through Scopus search engine. The full search code is similar to Ke et al. (2009) as the following: TITLE-ABSKEY (“PPP” OR “PFI” OR “BOT” OR “BT” OR “TOT” OR “BOOT”) AND TITLE-ABS-KEY (“Chinese” OR “China”) AND PUBYEAR AFT 2005 AND PUBYEAR BEF 2014 AND (LIMIT-TO(LANGUAGE, “English”)) AND (LIMITTO(SRCTYPE, “j”)). Eighty-six PPP International English Journal papers were identified in October 2015 at this stage.

2) Stage 2: Since PPP can also stand for many other specific terms such as Purchasing Power Parity in economy field, which is obviously not relevant with the current study, a double check is hence necessary to remove irrelevant papers. A quick review on the research relevance with PPP topic in the Construction Management field was carried out. As a result, 651 and 73 initial qualified papers were identified from Chinese and International Journals, respectively.

3) Stage 3: A comprehensive and in-depth review of the initial qualified PPP papers was conducted to identify publication date, research methods, research topics and findings, and nature of projects studied by researchers. At this stage, additional 36 papers from Chinese Journals and 3 papers from International Journals were abandoned, due to irrelevance to the current research or low quality (similarity of the research content, non-rigorous research process, etc.). The number of final valid PPP research papers was reduced to 615 and 70 in Chinese and International Journals, respectively.

During the overall research process, content analysis is the critical research method adopted in this study. According to Kolbe and Burnett (1991), content analysis is an effective observational research method to systematically evaluate the symbolic content of all forms of recorded communications. Fellows and Liu (2008) pointed out that content analysis is frequently used to determine the major facets of a set of data by simply counting the number of times that an activity happens or a topic is depicted. Both qualitative and quantitative content analysis methods are employed in this study. According to Fellows and Liu (2008), in qualitative content analysis, the emphasis is on determining the meaning of the data (i.e., grouping the data into categories), whereas quantitative content analysis extends this to generate numerical values of the categorized data, such as frequencies, ratings, and rankings, for further statistical analysis. Therefore, a comparison can be made and hierarchies of categories can be examined. As to qualitative content analysis, this study focused on the identification of research methods, research topics and findings, and project nature studied by researchers in both Journals. While quantitative content analysis is based on the qualitative results to statistically categorize and count the identified contents, with the assistance of EXCEL software.

Based on the above research process, the overall structure of PPP research was mapped and analysed in Chinese and International Journals in the last decade. 


\section{Chronology of PPP papers in Chinese and International Journals}

In order to know the development status of PPP research in the last decade, all the identified journal papers are categorized on yearly basis (see Table 2).

Table 2

Chronology of PPP papers in Chinese and International Journals.

\begin{tabular}{|c|c|c|c|c|c|c|}
\hline \multirow[t]{2}{*}{ Publishing year } & \multicolumn{2}{|l|}{ Chinese papers } & \multicolumn{2}{|l|}{ International papers } & \multicolumn{2}{|c|}{ Chinese + International papers } \\
\hline & Number of papers & Percentage & Number of papers & Percentage & Number of papers & Percentage \\
\hline 2005 & 50 & $8.1 \%$ & 2 & $2.9 \%$ & 52 & $7.6 \%$ \\
\hline 2006 & 61 & $9.9 \%$ & 2 & $2.9 \%$ & 63 & $9.2 \%$ \\
\hline 2007 & 63 & $10.2 \%$ & 2 & $2.9 \%$ & 65 & $9.5 \%$ \\
\hline 2008 & 58 & $9.4 \%$ & 3 & $4.3 \%$ & 61 & $8.9 \%$ \\
\hline 2009 & 56 & $9.1 \%$ & 12 & $17.1 \%$ & 68 & $9.9 \%$ \\
\hline 2010 & 60 & $9.8 \%$ & 14 & $20.0 \%$ & 74 & $10.8 \%$ \\
\hline 2011 & 67 & $10.9 \%$ & 9 & $12.9 \%$ & 76 & $11.1 \%$ \\
\hline 2012 & 56 & $9.1 \%$ & 8 & $11.4 \%$ & 64 & $9.3 \%$ \\
\hline 2013 & 62 & $10.1 \%$ & 11 & $15.7 \%$ & 73 & $10.7 \%$ \\
\hline 2014 & 82 & $13.3 \%$ & 7 & $10.0 \%$ & 89 & $13.0 \%$ \\
\hline Total & 615 & $100.0 \%$ & 70 & $100.0 \%$ & 685 & $100.0 \%$ \\
\hline
\end{tabular}

From Table 2, it is clear that number of PPP publications both in Chinese and International Journals experienced several rises and falls and reached peak in 2014, which appears to be consistent with the development pattern of the PPP models in Chinese construction industry.

Further analysis shows that, both Chinese and International Journals have produced more publications on PPP in the second five-year period (2010-2014) than first five-year period (20052009), with $13.5 \%$ and $133.3 \%$ increasing ratio, respectively.

From the above development status of PPP research in Chinese and International Journals, it appears that PPP research can still be categorized as a "hot" topic in China, considering the application status of PPP models and the promotion from the central government.

\section{Research methods adopted by PPP researchers}

Through content analysis method, the research methods of each paper are identified and counted, as shown in Table 3.

Table 3

Number of research methods used by PPP papers.

\begin{tabular}{|c|c|c|c|c|c|c|c|c|}
\hline \multirow{3}{*}{ Number of methods adopted } & \multicolumn{6}{|c|}{ Chinese papers } & \multirow{2}{*}{\multicolumn{2}{|c|}{$\frac{\text { International papers }}{2005-2014}$}} \\
\hline & \multicolumn{2}{|c|}{ 2005-2009 } & \multicolumn{2}{|l|}{ 2010-2014 } & \multicolumn{2}{|l|}{ 2005-2014 } & & \\
\hline & $\begin{array}{l}\text { Number } \\
\text { of papers }\end{array}$ & Percentage & Number of papers & Percentage & Number of papers & Percentage & $\begin{array}{l}\text { Number } \\
\text { of papers }\end{array}$ & Percentage \\
\hline 1 & 201 & $69.8 \%$ & 178 & $54.4 \%$ & 379 & $61.6 \%$ & 4 & $5.7 \%$ \\
\hline 2 & 46 & $16.0 \%$ & 61 & $18.7 \%$ & 107 & $17.4 \%$ & 24 & $34.3 \%$ \\
\hline 3 & 36 & $12.5 \%$ & 66 & $20.2 \%$ & 102 & $16.6 \%$ & 16 & $22.9 \%$ \\
\hline 4 & 3 & $1.0 \%$ & 21 & $6.4 \%$ & 24 & $3.9 \%$ & 15 & $21.4 \%$ \\
\hline 5 & 2 & $0.7 \%$ & 1 & $0.3 \%$ & 3 & $0.5 \%$ & 9 & $12.9 \%$ \\
\hline 6 & 0 & 0 & 0 & 0 & 0 & 0 & 2 & $2.9 \%$ \\
\hline Total & 288 & $100.0 \%$ & 327 & $100.0 \%$ & 615 & $100.0 \%$ & 70 & $100 \%$ \\
\hline Average number of methods/paper & 1.47 & & 1.80 & & 1.64 & & 3.10 & \\
\hline
\end{tabular}

Note: Since there are only 70 papers from International Journals, two periods breakdown analysis is not conducted.

For Chinese Journals, more than half (61.6\%) of the publications used only one research method in the last decade. Among the 379 single-research-method papers, 179 (47.2\%) PPP papers used the 
elaboration method. Here, elaboration or description, which is commonly used in Construction Management research field in China, refers to narrate, discuss, or depict the study without using other methods to support or validate the research findings. As to the International Journals, there is a sharp contrast with Chinese Journals, since there is only $5.7 \%$ of the publications using single research methods. The statistics also show that the average number of research methods per paper is 1.64 and 3.10 for Chinese and International Journals respectively.

In Construction Management field, more research methods are better to cross validate the research findings, which makes the study more rigorous and convincing. From this point of view, improvements should be made for Chinese Journals to catch up with the International Journals on PPP topics. And obviously, Chinese studies have shifted in this direction, since the average number of research methods per paper has increased from 1.47 in first five-year period to 1.80 in second five-year period.

\subsection{Detailed analysis of different research methods adopted by PPP researchers}

Before successfully conducting PPP research, it is important to decide the proper research methods to be used. In Construction Management field, there are four typical research methods: literature review, case study, interview and questionnaire survey (Tang, 2011). Based on the content analysis results, various research methods adopted in PPP research papers are reported in Table 4.

Table 4

Research methods adopted by PPP research papers.

\begin{tabular}{|c|c|c|c|c|c|c|c|c|}
\hline \multirow{3}{*}{ Research method } & \multicolumn{6}{|c|}{ Chinese papers } & \multirow{2}{*}{\multicolumn{2}{|c|}{$\frac{\text { International papers }}{2005-2014}$}} \\
\hline & \multicolumn{2}{|l|}{ 2005-2009 } & \multicolumn{2}{|l|}{ 2010-2014 } & \multicolumn{2}{|l|}{$2005-2014$} & & \\
\hline & $\begin{array}{l}\text { Number of } \\
\text { methods }\end{array}$ & Percentage & $\begin{array}{l}\text { Number of } \\
\text { methods }\end{array}$ & Percentage & $\begin{array}{l}\text { Number of } \\
\text { methods }\end{array}$ & Percentage & $\begin{array}{l}\text { Number of } \\
\text { methods }\end{array}$ & Percentage \\
\hline Case study & 120 & $28.4 \%$ & 168 & $28.6 \%$ & 288 & $28.5 \%$ & 43 & $19.8 \%$ \\
\hline Literature review & 69 & $16.3 \%$ & 133 & $22.7 \%$ & 202 & $20.0 \%$ & 57 & $26.3 \%$ \\
\hline $\begin{array}{l}\text { Modeling (game theory, NPV, fuzzy } \\
\text { theory, AHP, system dynamics, } \\
\text { real option, etc.) }\end{array}$ & 72 & $17.0 \%$ & 120 & $20.4 \%$ & 192 & $19.0 \%$ & 11 & $5.1 \%$ \\
\hline Elaboration & 101 & $23.9 \%$ & 78 & $13.3 \%$ & 179 & $17.7 \%$ & 0 & $0.0 \%$ \\
\hline $\begin{array}{l}\text { Questionnaire survey (questionnaire } \\
\text { survey, factor analysis, regression } \\
\text { analysis, etc.) }\end{array}$ & 27 & $6.4 \%$ & 37 & $6.3 \%$ & 64 & $6.4 \%$ & 62 & $28.6 \%$ \\
\hline Comparison & 28 & $6.6 \%$ & 26 & $4.4 \%$ & 54 & $5.3 \%$ & 26 & $12.0 \%$ \\
\hline $\begin{array}{l}\text { Other methods (Monte Carlo simulation, } \\
\text { interview, grounded theory, etc.) }\end{array}$ & 6 & $1.4 \%$ & 25 & $4.3 \%$ & 31 & $3.0 \%$ & 18 & $8.3 \%$ \\
\hline Total & 423 & $100.0 \%$ & 587 & $100.0 \%$ & 1010 & $100.0 \%$ & 217 & $100.0 \%$ \\
\hline
\end{tabular}

Note: Some papers have more than one research methods.

It can be seen from Table 4 that, for Chinese Journals, case study is the most popular research method (28.5\% of total methods) adopted by PPP researchers, followed by literature review (20.0\% of total methods) and modelling (19.0\% of total methods). In contrast, questionnaire survey is most frequently used in PPP studies (28.6\% of total methods) in International Journals, followed by literature review (26.3\% of total methods) and case study (19.8\% of total methods).

According to Taylor and Jaselskis (2010), experimental research and survey research methods were most frequently used in Construction Management and Engineering, based on the examination of 1102 articles published from 1993 to 2007 in Journal of Construction Engineering and Management, which is significantly different with the results of this study. 


\subsubsection{Case study and its application in PPP field}

The objectives of using case study is to identify the common and unique features, to identify or attempt to identify various interactive process at work, and to show how they affect the implementation of systems (Tang, 2011). Due to the complication of PPP approach and unique feature of the project, the organizational structure, risk and profit sharing strategy, and financing model are different from project to project, and consequently PPP project management is projectspecific and very sophisticated. In addition, PPP project always involves a large capital investment and has a significant influence on the public image. Therefore, the public entity is prudent before choosing PPP approach as the project delivery method, which leads to PPP being much less popular comparing with other approaches (e.g. Traditional, Design-Build (DB), and Construction Management at risk) in delivering a public project in China. From this point of view, case study shall be a more suitable and effective research method in summarizing the best practices of managing PPP projects. A comprehensive elaboration of PPP project management case will enable other practitioners to learn the knowledge and experience in depth to increase the chances of project success.

Some researchers used typical Chinese PPP projects as the cases in their study. Zhang and Wang (2013) explored the PPP financing model for the cross-sea channel of Bohai Strait in China. Cheung and Chan (2009) attempted to find out the successful traits for BOT projects using Hong KongZhuhai-Macau Bridge as the case. Shen et al. (2006) used the example of Hong Kong Disneyland to demonstrate how various major risks in PPP project were allocated and shared effectively between public and private partners. There are also other researchers using western PPP projects as the cases. Ke et al. (2008) summarized lessons learned from the improper risk allocation leading to the failure of Channel Tunnel. Song (2012) analysed the important decision procedure for railway PPP projects using a railway project in South Africa as the case. Both successful and failed case PPP projects have been analysed by PPP researchers. For example, it was concluded by Yin and Yin (2013) that proper risk allocation in Beijing Subway Line 4 is one of the Critical Success Factors (CSFs) for PPP project. In contrast, Qi et al. (2009) used 16 failed PPP case projects to identify the primary risk factors and proposed countermeasures to effectively manage these risks.

Sometimes, single case study would not be robust enough to draw a conclusion which is generally applicable to other scenarios in PPP models. Hence, multi-case study or comparative case study methods were frequently adopted by PPP researches to produce more powerful and comprehensive conclusions. For example, Song et al. (2013) used several foreign PPP infrastructure projects to illustrate three basic flexible concession period decision models; Du and Wang (2013) compared three domestic PPP cases to explore factors influencing the allocation of control rights between public and private entities; and Xu et al. (2011) identified the risk factors and summarized the risk allocation practices through comparative analysis of nine Chinese PPP water projects.

\subsubsection{Literature review and its application in PPP field}

Literature review is a typical research method to help researchers to understand the development trend in the research field. Literature review is not just about reading the relevant research publications but rather about presenting critiques of existing works to identify the knowledge gaps (Yeung, 2007). Most of the PPP papers use this method as a basis to identify knowledge gaps, to summarize research progress or to consolidate research findings. Zhang et al. (2010), Sun and Ye (2013), Guo (2013) and Gao et al. (2014) identified the knowledge gap from a broad view in their specific research topics respectively. Deng et al. (2008) elaborated the proper risk allocation method through literature review and case study method. Chan et al. (2010) identified the CSFs for PPP 
project based on extensive review of published literature. Sun et al. (2012) developed a KPIs (Key Performance Indicators) structure to effectively evaluate PPP project performance. There are also PPP researchers using literature review as the sole research method to construct a research framework. For example, Wang et al. (2009) used literature review method to develop concession period decision model in BOT projects; Du and Yin (2011) identified the methods and principles of risk allocation between PPP participants on the basis of extensive literature review; and S.B. Zhang et al. (2014) conducted the critical review on governance issue in PPP project and proposed future research directions under the topic. Statistical analysis also shows that literature review was adopted by $32.8 \%$ and $81.4 \%$ of PPP papers in Chinese and International Journals, respectively. Therefore, a significant difference exists in these two cluster of publications in the popularity of applying this method.

\subsubsection{Modelling and its application in PPP field}

Modelling method in PPP research refers to validating a particular PPP research theme through a model verification process based on game theory, NPV (Net Present Value), fuzzy theory, AHP (Analytic Hierarchy Process), system dynamics, and so on. Wang et al. (2007) established a risk allocation model between the public and private partners on basis of game theory. Wang and Li (2008) constructed the early warning risk system for private entity by applying fuzzy set theory and matter-element theory. Li et al. (2010) used system dynamics model to develop price adjustment mechanism in optimizing the satisfaction of multi-stakeholders. Further analysis shows game theory and NPV are two most popular modelling development instruments in conducting PPP research. Game theory was applied to two main research topics as concession period decision (e.g. Zhang and Wang, 2012; Liu et al., 2012) and risk allocation (e.g. He and Zhao, 2011; Wang et al., 2013). Since the decision of concession period and risk allocation involves complex bargain between the stakeholders, it is reasonable to use game theory to explore the sophisticated decision process or to establish interest-optimization models. On the contrary, NPV modelling is most popular in two main themes as the investment/price decision (e.g. Zhu and Qiu, 2011; Hu et al., 2010) and the concession period decision (e.g. Wang et al., 2010; Song et al., 2010). Since concession period decision is closely related to the return on investment and price of the services or products, the settlement of these two issues relies heavily on the proper development of NPV model in most cases. In contrast to the popularity of modelling method in Chinese Journals (31.2\% of total papers), this method is not frequently used in International Journals (15.7\% of total papers), where fuzzy theory (e.g. Xu et al., 2010) and NPV (e.g. Liu and Cheah, 2009) are two main modelling development instruments for this research method.

\subsubsection{Questionnaire survey and its application in PPP field}

In questionnaire survey, the target respondents are asked the same and standard questions using a pre-designed survey instrument (Bell 2005). This method is generally considered as one of the most popular methods in the Construction Management research field (Chow, 2005). Due to the sophistication of the PPP approach, special attention should be paid to the selection of suitable respondents with PPP management knowledge or experience to get reliable opinions.

In PPP research papers, Li and Zou (2008) used questionnaire survey approach to gain a comprehensive understanding of contractor's risk perceptions of PPP projects. Chan et al. (2009) conducted empirical questionnaire survey to explore and compare the key drivers for adopting PPP in China and Hong Kong. Yuan et al. (2010b) adopted structured questionnaire survey to investigate the relative significance of PPP performance objective attributes in four stakeholder groups. In contrast with the general questionnaire survey method used in Chinese Journals, Delphi survey 
method is more frequently adopted by publications in International Journals, such as Xu et al. (2010) and Ke et al. (2010b) in conducting risk allocation studies. This method has been increasingly used in many complex fields where a consensus is needed to be reached (Xu et al., 2010). Since the information collected requires in-depth knowledge and sound experience of PPP models, Delphi survey method shall be more suitable and rigorous to collect reliable information from the industry or academia in PPP study, compared with general questionnaire survey method.

\subsubsection{Comparison and its application in PPP field}

Contrary to other analysis techniques, comparison is simple but effective to produce powerful and rigorous conclusions. There are various comparison perspectives and strategies in studying PPP topics, either by analysing the differences between the practices/legal systems in different countries/territories/sectors or by comparing different implementation frameworks in specific PPP case projects. For example, Gurgun and Touran (2014) conducted a comprehensive research on the legal system of PPP models in different countries; H. Sun et al. (2011) made comparison on different renegotiation strategies and their efficiency for PPP projects in Latin America area; and Hu et al. (2011) analysed different risk allocation methods through comparing three PPP approaches, i.e. Build-Transfer-Operate (BTO), BOT and Build-Own-Operate (BOO).

Statistical analysis reveals that comparison method is frequently used both in Chinese and International Journals. However, the difference in adopting this method is also clear. International Journals used this method in a much broader view than Chinese Journals, such as cross-country comparison for various PPP models in different countries (e.g. Phang, 2007; Willoughby, 2013); cross-country comparison on the CSFs of PPP model in China and UK (e.g. Chan et al., 2010); or cross-territory comparison on the CSFs of PPP model between Mainland China and Hong Kong (e.g. Cheung et al., 2012); and cross-industry comparison on the risk factors of PPP model (e.g. Cheung and Chan, 2011). However, such research is very limited in numbers in Chinese Journals. Obviously, the readers are able to get a better contextual understanding regarding the specific PPP topic from the broad-view comparison in International Journals.

\subsection{Detailed analysis of qualitative and quantitative methods adopted by PPP researchers}

There are also qualitative and quantitative approaches in research field. Qualitative research methods primarily obtain qualitative data regarding behaviour, phenomenon, pattern, etc. In contrast, quantitative research is the examination, analysis and interpretation of observations for the purpose of discovering underlying meanings and patterns of relationships, including classifying the types of phenomena and entities (Marshall and Rossman, 1998).

Although there is a common distinction between qualitative and quantitative methods, both methods are frequently adopted in a particular research simultaneously. In order to analyse these two methods adopted by PPP researchers, and to avoid duplication of the statistics, this study will consider either qualitative or quantitative methods being used by a particular paper. Based on this hypothesis, the statistical analysis result of these two methods adopted by PPP researchers is illustrated in Table 5.

The table clearly demonstrates that, in Chinese Journals, qualitative method (63.7\% of total papers) is more frequently adopted than quantitative method (36.3\% of total papers). In contrast, there are more papers using quantitative method (54.3\% of total papers) than qualitative method ( $45.7 \%$ of total papers) in International Journals. 
Qualitative or quantitative methods adopted by PPP researchers.

\begin{tabular}{|c|c|c|c|c|c|c|c|c|}
\hline \multirow{3}{*}{ Research methods } & \multicolumn{6}{|l|}{ Chinese papers } & \multirow{2}{*}{\multicolumn{2}{|c|}{$\frac{\text { International papers }}{2005-2014}$}} \\
\hline & \multicolumn{2}{|l|}{ 2005-2009 } & \multicolumn{2}{|l|}{ 2010-2014 } & \multicolumn{2}{|l|}{ 2005-2014 } & & \\
\hline & Number of papers & Percentage & Number of papers & Percentage & Number of papers & Percentage & Number of papers & Percentage \\
\hline Qualitative & 202 & $70.1 \%$ & 190 & $58.1 \%$ & 392 & $63.7 \%$ & 32 & $45.7 \%$ \\
\hline Quantitative & 86 & $29.9 \%$ & 137 & $41.9 \%$ & 223 & $36.3 \%$ & 38 & $54.3 \%$ \\
\hline Total & 288 & $100.0 \%$ & 327 & $100.0 \%$ & 615 & $100.0 \%$ & 70 & $100.0 \%$ \\
\hline
\end{tabular}

\section{Research topics of PPP papers in Chinese and International Journals}

Based on the content analysis and statistical analysis results (see Table 6), for both Chinese and International Journals, it was found that PPP models and their application are the most popular research topic (35.8\% and $47.6 \%$ of total research topics, respectively), followed by risk management ( $21.7 \%$ and $26.8 \%$ of total research topics, respectively).

Table 6

Research topics of PPP papers in Chinese and International journals.

\begin{tabular}{|c|c|c|c|c|c|c|c|c|}
\hline \multirow{3}{*}{ Research topic } & \multicolumn{6}{|c|}{ Chinese papers } & \multirow{2}{*}{\multicolumn{2}{|c|}{$\frac{\text { International papers }}{2005-2014}$}} \\
\hline & \multicolumn{2}{|c|}{ 2005-2009 } & \multicolumn{2}{|c|}{ 2010-2014 } & \multicolumn{2}{|c|}{ 2005-2014 } & & \\
\hline & $\begin{array}{l}\text { Number } \\
\text { of topics }\end{array}$ & Percentage & $\begin{array}{l}\text { Number } \\
\text { of topics }\end{array}$ & Percentage & $\begin{array}{l}\text { Number } \\
\text { of topics }\end{array}$ & Percentage & $\begin{array}{l}\text { Number } \\
\text { of topics }\end{array}$ & Percentage \\
\hline $\begin{array}{l}\text { PPP models and their application (different PPP models, } \\
\text { application of PPP models, model selection, CSFs, } \\
\text { performance issue, etc.) }\end{array}$ & 122 & $39.7 \%$ & 120 & $32.5 \%$ & 242 & $35.8 \%$ & 39 & $47.6 \%$ \\
\hline $\begin{array}{l}\text { Risk management (risk factors, evaluation, allocation, and } \\
\text { control, etc.) }\end{array}$ & 69 & $22.5 \%$ & 78 & $21.1 \%$ & 147 & $21.7 \%$ & 22 & $26.8 \%$ \\
\hline $\begin{array}{l}\text { Financing and economic issue (financing, price setting, project } \\
\text { cost or value, investment issue, concession period issue, etc.) }\end{array}$ & 49 & $16.0 \%$ & 94 & $25.5 \%$ & 143 & $21.2 \%$ & 3 & $3.7 \%$ \\
\hline $\begin{array}{l}\text { Legal and procurement issue (laws and regulations, procurement, } \\
\text { contract, etc.) }\end{array}$ & 29 & $9.4 \%$ & 29 & $7.9 \%$ & 58 & $8.6 \%$ & 8 & $9.8 \%$ \\
\hline $\begin{array}{l}\text { Government regulation and guarantee (government regulation, } \\
\text { allocation of control rights, government guarantee, etc.) }\end{array}$ & 28 & $9.1 \%$ & 25 & $6.8 \%$ & 53 & $7.8 \%$ & 6 & $7.3 \%$ \\
\hline $\begin{array}{l}\text { Management and other issues (knowledge management, } \\
\text { change management, safety management, trust, etc.) }\end{array}$ & 10 & $3.3 \%$ & 23 & $6.2 \%$ & 33 & $4.9 \%$ & 4 & $4.9 \%$ \\
\hline Total & 307 & $100.0 \%$ & 369 & $100.0 \%$ & 676 & $100.0 \%$ & 82 & $100.0 \%$ \\
\hline
\end{tabular}

Note: Some papers have more than one topics.

In contrast to the above results, another study conducted by Ke et al. (2009) showed that the popularity of PPP research topics in leading international Construction Management journals in descending order are risk management, integration research, governance issue, investment environment, procurement, economics viability and financial package.

However, both results highlight the importance of risk management research in PPP body of knowledge.

\subsection{PPP models and their application}

From 1990s, more than 1000 PPP projects has been implemented in China with total investment of exceeding 140 billion USD, which encompasses transportation, telecommunication, energy resources, water supply, etc. The application of PPP model has improved the management performance, expanded the public service sphere, and reduced project cost (MoF, 2014b). Hence, PPP has played a very important role in developing the infrastructure systems in China. In PPP family, there are varieties of models, such as BOT, BT, TOT, etc. The first decision to be made when using PPP approach is to choose the model which is best sui to the proposed project. In China, most of the PPP projects are implemented with BOT model (Hu et al., 2012). Whereas in USA, 65\% of the PPP projects use BOT/BTO model, 24\% of them use DB/Design-Build-Operate-Maintenance 
(DBOM) model, 10\% use Design-Build-Finance-Operate (DBFO) model, and only 1\% use BOO model, according to the data from 1985 to 2004 by Federal Highway Administration (Wang and Wang, 2013). In addition, most of the PPP projects in China relies on the finance from banks. However, experience from developed countries shows other financing channels, such as security and bonds, are also effective to provide funding, considering the large amount of capital investment for PPP project (MoF, 2014a). From this point of view, it is suggested to further study different PPP models and to actively promote the variety of application matching with particular project type in Chinese construction market.

Further statistical analysis reveals that the research under this heading mainly focuses on two areas: developing new PPP models, and application of various PPP models in particular sectors or project types. For example, Liu and Chen (2005) constructed a new C-BOT model as an innovation strategy to effectively develop the infrastructure systems in small and medium cities in China. Ng et al. (2013) advocated a Public Private People Partnerships (P4) process which put people as a major stakeholder for implementing PPP schemes to capture social concerns at different stages of PPP project. These publications also explored the application of PPP models in various sectors, e.g. urban renewal (Li, 2012), city development (Wang et al., 2008), and water sector (Lee, 2010; Chen and Messner, 2005); and in different nature of projects, e.g. subway (Chang, 2013), public housing (Yuan et al., 2012), large-scale public venue (Liu and Wilkinson, 2014), and water plant (Chen, 2009).

The main conclusions from these studies were that government departments in China were active in applying PPP models in various sectors and different type of projects, but the application process had also met challenges and obstacles. For example, the most important driving factors in applying BOT model in China was to get infrastructure development capital (Chen and Doloi, 2008), and the most important driving factors to adopt PPP in transportation projects were to obtain public benefits and better public service (Yuan et al., 2010a). However, the most significant impeding factors in applying BOT are opaque and inadequate legal system (Chen and Doloi, 2008). The identified CSFs for applying PPP models in China were stable macroeconomic environment, shared responsibility between public and private sectors, transparent and efficient procurement process, stable political and social environment, and judicious government control (Chan et al., 2010). However, according to the international PPP application experience, there were three CSFs in initiating PPP project: proper legal system, governance environment and government capability; competitive financing capabilities of public and private partners; and good project planning and risk allocation system (MoF, 2014b).

\subsection{Risk management}

In PPP project, various risks exist not only due to the complexity of the financing and organizational structure of the project, but also due to the large amount of investment, long operation period (15-99 years), sophisticated technical know-how of the project (e.g. power plant, subway, and water treatment plant), political impact, government involvement, etc. Therefore, it is critical for the project participants to comprehensively identify and evaluate the risks factors in PPP project lifecycle and to properly allocate all the risks between them. There are two main themes in PPP risk management field, i.e. identification \& evaluation of risk factors (e.g. Jin et al., 2007; Chen et al., 2011), and proper allocation of risk factors between the project participants (e.g. Guo, 2013; He and Zhao, 2011; Wang et al., 2007). Empirical study showed that the three most important risk factors of PPP projects in China are: government intervention, government corruption, and poor public decision-making processes (Chan et al., 2011). Another research also concluded government risks as the most critical risks in Chinese water sectors (Xu et al., 2011). As to the risk allocation theme, most of the studies in Chinese Journals focused on proposing an optimized allocation model using 
qualitative method. For example, Deng et al. (2008) summarized nine principles in allocating PPP project risks, i.e. justice principle, liability principle, principle of risk and profit equivalence, efficiency principle, etc. A typical quantitative research method in risk allocation in International Journals is questionnaire survey, for example Ke et al. (2010b) and Chan et al. (2011).

Although risk management topic in Chinese Journals covered various research fields, few research conducted comparative study on risk management practices in different countries/territories or sectors, to enable practitioners and academia in China to better understand the risk management issue. Additionally, in risk allocation theme, most of the studies paid attention to which risks should be allocated to certain stakeholders, i.e. government or private entity, limited study focused on proposing a realistic risk sharing strategy or reasonable risk sharing ratio between the parties. Last but not least, most of the risk management research in Chinese Journals halted at identification of risk factors, the quantitative evaluation of risk probability, risk impact and risk significance for these factors, similar to the study by Chan et al. (2011), is still not available.

In Chinese Journals, qualitative research method is more frequently (62.8\% of risk management papers) adopted in risk management studies; whereas in International Journals, quantitative is more popular to researchers (69.2\% of risk management papers). However, in recent years, more rigorous and complicated methods were increasingly adopted by risk management researchers in Chinese Journals, such as real option theory (Guo, 2013), integration of Fuzzy AHP and Fuzzy Comprehensive Evaluation theory (Zhao and Tu, 2011), and game theory (He and Zhao, 2011; Wang et al., 2007). This trend is similar to the findings from Ke et al. (2009).

\subsection{Financing and economic issues}

PPP project usually involves large capital investment and long-period of operation to realize the expected return on investment through selling the services or products to the public. Therefore, financing and price of the services or products are focus of the stakeholders involved in the PPP project. Under this topic, three questions have to be satisfactorily answered before the stakeholders committing resources or investment to the project: How much money is needed for the project from the conception to the end of concession period? Where is the money coming from? Whether there is a reasonable return on investment? In order to answer these questions, there are several critical parameters which shall be calculated or forecasted, including project completion cost (design, construction, installation, etc.) and operation cost, price of the services or products, concession period, funding structure and financing cost, subsidy from the government, repurchase payment from the government (BT project), etc. For these parameters, completion cost is more easily determined since most of the factors to be considered is simpler and static in the cost estimation process. However, the remaining parameters are dynamic, difficult to forecast, or interrelated, for example, subsidy from the government has a direct influence on the price of services or products. Therefore, PPP study on financing and economic issue attempts to find answers to the above three questions, especially to establish models in ascertaining these variables, on basis of modelling or various theories. For example, Yin and Jiang (2011) studied the critical points of investment control in PPP project conception stage, feasibility study stage and design stage using Shenzhen Subway as the example. Chen and Zheng (2011) explored the factors affecting the price of public PPP renting housing project. Song et al. (2010) identified concession period influencing factors and proposed a concession period decision model through NPV and Monte Carlo simulation method. Zhao and You (2013) established a model to determine the ceiling and bottom of compensation funding from the government on perspective of social benefit and return on investment. 
It is a key issue, under financing and economic topic, to decide a reasonable and acceptable concession period between the parties in contract negotiation stage, because the length of period is closely related with the return on investment in PPP project. Some projects in China, with fixed 30 years of concession period, achieved very high operation revenue and consequently got unreasonably high ratio of return on investment, which resulted in a seriously negative social impact, such as a flight highway in Beijing, a bridge in Guangdong province, a water plant in Shenyang City, to name a few. However, there are also case projects to extend the concession period during the operation stage because the project can not realize the expectation on investment, which may lead to failure of the project, for example, the concession period of Channel Tunnel was extended from 55 years to 99 years by the government (Song et al., 2013). Literature analysis shows that there are three main methods or perspectives to conduct research on concession period decision, i.e. capital price, bargain between the parties based on game theory, and NPV theory (Zhao and Tan, 2009). Since it is difficult to determine concession period with large amount of parameters being considered and to accurately forecast the parameter fluctuation with dynamic nature because of long-term operation, flexible concession period decision method has been adopted increasingly as an alternative instead of fixed decision method. In this regard, Wang et al. (2009) conducted a comparative study on the two decision methods and proposed research directions in these fields; Song et al. (2013) compared the characteristic and application conditions of three sub-category of flexible concession period decision methods, i.e. single-parameter revenue decision model, multi-parameter revenue decision model, and renegotiation model.

The price of services or products in PPP project determines the cash flow in operation stage and the project value. It also has a direct impact on the social welfare (Ye and Yang, 2012), incentive level of the private partners involved in the project, and service level of private entity in operation stage (Kuang et al., 2008). For some of the projects, the operation revenue is not sufficient to pay back the investment, where government subsidy is a must for compensation. In general, there are two main types of compensation from the government, i.e. subsidy at the construction stage and subsidy at the operation stage (Kuang et al., 2008). In the former, government will be responsible for financing and constructing part of the project, and hand-over the project after completion to private partner for operation. Whereas in the latter, government will mainly compensate the operation cost based on the actual cash flow calculation.

All in all, for PPP projects, the investment scheme/model, with above parameters being considered, should be carefully evaluated by government to not only attract the active participation from the private entity, but also to avoid unreasonable high return on investment. Attention should also be paid to the fact that a certain kind of scheme/model which may be applied successfully to a specific project type, e.g. subway and highway PPP project (as studied by Ye, 2012; Zhao and You, 2013), may not be suitable to other type of PPP projects, e.g. wastewater treatment plant project (as studied by Song et al., 2010). From this point of view, further research should be conducted to study the financing and economic issue for various sectors or different types of projects in a specific PPP model.

\subsection{Legal and procurement issues}

Since PPP project is initiated to meet the public needs with a particular model, whether it is BOT, BT or BOOT, it is necessary to establish a comprehensive legal framework to guide the overall process, and to define rights and responsibilities of all the stakeholders involved, especially the government entity and private sponsors. In other words, a well-established and structured legal system is critical to promote the application of PPP models in construction industry (Gurgun and Touran, 2014). At present, many countries have developed an independent legal system for PPP model, such as USA, 
South Korea, Brazil and Argentina (Zhang et al., 2014a). China has also issued more than 50 management regulations on PPP models. However, the establishment of systematic law and policy structure in the national level is still undergoing in China to regulate PPP project life-cycle management (MoF, 2014a). There are several problems in the existing legal and procurement systems for PPP model in China, such as conflicting regulations, non-national level enforcement, absence of regulations on particular aspects of PPP application (Wang, 2014a). As addressed by some studies (e.g. Yuan et al., 2007; Ye et al., 2011; J.Z. Zhang et al., 2014), the immature legal system has become one of the main impeding factors for the application of PPP models in China. However, most of the existing research under this topic paid more attention to identify the problems of the current PPP legal systems, instead of developing an applicable and country-tailored PPP legal framework to ascertain the successful application in China.

In PPP project, it is also critical for public entity to select a competitive and suitable private sponsor, and to sign an enforceable contract to properly share the rights and responsibilities between them. In PPP project, the procurement process is much more complicated due to the complex contract structure, large amount of stakeholders involved, special features of PPP model, etc. Consequently, considerable costs and resources are committed to the procurement process in PPP project, for example, the tendering cost reached $2.6 \%$ of overall investment, and the procurement process lasted 34 months in UK PPP projects (Zhang et al., 2012). In addition, Value for Money has to be considered to optimize the public interests for PPP projects. Therefore, there should be a national regulation in China to guide the standard procurement process of PPP project to protect the public interest, avoid corruption, improve the efficiency, and so on. Furthermore, drafting contract for a particular PPP project is time and cost consuming, considering the complication of PPP projects and specialization of construction contract. However, such procurement guidance and standard conditions of contracts, which can be applied to different type of projects or various sectors in different PPP models, are still in the development process in China. Currently, most of the publications in this area focused on the PPP contract re-negotiation (e.g. H. Sun et al., 2011), PPP contract system and arrangement (e.g. Zhang et al., 2011), tendering documentation analysis (e.g. Zhang et al., 2012), design of competitive tendering mechanism (e.g. Yan and Wang, 2009). Few studies on the legal and procurement issue proposed applicable and in-depth suggestions, as Yuan et al. (2007); Ye et al. (2011), and Wang (2014b) did. Therefore, efforts from researchers should be applied to study the systematic legal systems, procurement process, and conditions of contract which are applicable to PPP models in Chinese construction industry.

\subsection{Government regulation and guarantee}

Since the initiation of PPP projects is a government action, the procurement and implementation process is naturally monopolized. World Bank defines regulation in PPP model as directly or indirectly controlling the decision or behaviour of private entities, government or other participants, and clearly states that it is necessary to provide a proper regulation for PPP projects to achieve success (S.B. Zhang et al., 2014). The purpose of regulation is to protect the investors and avoid the optional intervention by government, and to safeguard against the public interest and avert the opportunism behaviour, as well as to establish a trust between the government and private entities (S.B. Zhang et al., 2014). Other studies (e.g. Chen and Hubbard, 2012) demonstrated that in a contractual relationship, the party with more power were able to shift risk or cost to the weaker parties. In PPP projects, the government is a much more powerful party comparing with private entities. Therefore, effective regulation system should be established to enhance the governance of PPP projects in China. 
One of the most important issues in government regulation is to decide the allocation of control rights, because proper allocation of control rights is critical to the cooperation efficiency between the parties (Du and Wang, 2013), and the rational decision behaviour of the participants (Hu, 2012). The control right allocation, together with risk allocation and profit sharing, should be negotiated as an integration in the project procurement stage, and clearly stated in the contract between the government and private entities. Since the three issues are interrelated and interdependent, they should be matched with each other to optimize the performance of each party. According to the incompleteness of contract nature, Du and Wang (2013) classified the contractual control rights as specific control rights and residual control rights. Hu (2012) conducted study on the control rights from a different perspective, and considered there were three types of PPP models according to various methods of allocating control rights in construction period, concession period and postconcession period. For example, in BTO model, government has the control rights in all three stages; whereas in BOT model the private sponsor has the control rights in the concession period. Therefore, they are inherently two different PPP models. From this point of view, the selection of PPP models will accordingly determine the allocation of control rights. Other researches in this field include the allocation of residual control rights under incomplete contracts (Sun and Ye, 2013), the experience of PFI project regulation in U.K. (Hu et al., 2006), and the critical ingredients of good governance in Hong Kong perspective (Hayllar, 2010). Most of the researches in this theme also highlighted the importance of an independent national institution in supervising the application of PPP model.

However, at present, there is no central institution taking the responsibility of developing the national PPP strategy, supervising the life-cycle implementation of PPP projects, and ensuring the compliance of PPP projects with national plan objectives in China. But such central unit in Australia, U.K., South Africa and Turkey (Gurgun and Touran, 2014), has been in function to guide the public entities in procuring the public works. In fact, it is urgent to carry out relevant research on the establishment of a central institution in administrating the development of PPP model in China.

In order to improve the attractiveness of PPP project to the private entity, the government usually provide various kinds of guarantees, such as services or products purchasing guarantee, competition restriction guarantee, minimum level of return on investment or revenue. For example, the Channel Tunnel was guaranteed by the government that there would be no second transportation option being constructed in 33 years to restrict the competition (Zhao et al., 2008). The government guarantee can also enhance the confidence level of the private sponsors (Zhao et al., 2008), optimize the government decision and improve the social benefits (Tan and Tan, 2008), and improve the profit level (Zhao et al., 2009). From this point of view, government guarantee is critical for the success of PPP projects. Therefore, many studies focused on this issue. For example, Zuo et al. (2008) classified the type of government guarantees and discussed the proper application conditions for each type of guarantee; Tan and Tan (2008) quantitatively studied the government guarantee issue under heterogeneous beliefs; Zhao et al. (2009) conducted comparative studies on two type of government guarantees, i.e. product purchasing guarantee and competition restriction guarantee; and Y.F. Sun et al. (2011) explored the accounting issues of government guarantee. It is obvious that excessive guarantee from the government will also reduce the efficiency and lead to inequity in PPP project. However, existing studies in Chinese Journals under this theme have not established an optimization level of government guarantee in the best interest of the public. In addition, most of the researches focused on BOT project, and few studies conducted research based on other type of PPP models.

\section{Nature of projects studied in PPP papers}

The nature of projects studied in the PPP papers is also categorized and shown in Table 7. 


\begin{tabular}{|c|c|c|c|c|}
\hline \multirow[t]{2}{*}{ Nature of projects } & \multicolumn{2}{|c|}{ Chinese papers (2005-2014) } & \multicolumn{2}{|c|}{ Intemational papers (2005-2014) } \\
\hline & Number of papers & Percentage & Number of papers & Percentage \\
\hline $\begin{array}{l}\text { Infrastructure (subway, highway/road, sewage/waste water } \\
\text { treatment plant, power plant, railway, bridge, etc.) }\end{array}$ & 305 & $49.6 \%$ & 35 & $50.0 \%$ \\
\hline Public housing project & 28 & $4.6 \%$ & 2 & $2.9 \%$ \\
\hline $\begin{array}{l}\text { Other projects (city development, recreation project, } \\
\text { hospital, sustainable development, construction waste } \\
\text { treatment, etc.) }\end{array}$ & 85 & $13.8 \%$ & 13 & $18.6 \%$ \\
\hline NA & 197 & $32.0 \%$ & 20 & $28.6 \%$ \\
\hline Total & 615 & $100 \%$ & 70 & $50.0 \%$ \\
\hline
\end{tabular}

According to Table 7, for the three categories of projects, both Chinese and International Journals have the similar share of percentage, and half of the publications (49.6\% and $50.0 \%$ respectively) concentrated on the study of infrastructure projects, such as subway, highway/road, etc. There are also $32.0 \%$ and $28.6 \%$ of the papers being not relevant to any particular project nature in Chinese and International Journals, respectively.

Further analysis is conducted for Chinese Journals to break down the project nature in the cluster of infrastructure, and the result shows that subway, road/highway, and sewage/waste water treatment plant are three most frequently studied infrastructure projects, with $25.9 \%, 20.3 \%$ and $8.5 \%$ of the cluster, respectively. For example, as the typical successful PPP project in China, Shenzhen Subway Line 5 is the most frequently quoted case in Chinese Journal papers, with 19 publications using it as the research sample.

From the 1980s, with the fast development of economy in China, the infrastructure construction has entered a rapid development period. Specifically, Four Trillion RMB Stimulus Plan was initiated by the central government at the end of 2008 to boost the domestic demand mainly through constructing massive infrastructure projects in China, and only 1.18 trillion came from the central government, the rest would be covered by the local government, and/or the private sector (Ke et al., 2010a). Consequently, more infrastructure projects have been on the track for construction from then on. However, infrastructure projects need large capital investment from the government, and the involvement of private entities can significantly reduce the finance burden. Hence, it is not surprising to find that infrastructure project has the largest share of PPP projects, and is also most attractive to PPP researchers in China. The situation seems to be similar with other developing countries, where the primary investments to deliver the key infrastructure projects come from the private sector (Public-Private Infrastructure Advisory Facility, 2012).

As to the different nature of infrastructure projects, highway and subway are more suitable to use PPP model, because return on investment is more reliable through the operation of the project. As a consequence, there are more highway and subway PPP projects implemented in recent years in China. For example, the Jing Cheng Highway, Jing Ping Highway, Jing Shen Zhu Highway, and Shanghai South Circle Highway have been successfully constructed and operated using BOT approach (Guo, 2013). Subway investment is also one of the largest public investments in the infrastructure sector, with active investment from private entity. Some of the sample subway PPP projects are Beijing Subway Olympic Line, Shenzhen Subway Line 5, and Beijing Subway Line 4 project (Yan and Cui, 2011). The sample subway projects using PPP model in China is shown in detail in Table 8. 
Table 8

Example PPP subway projects in China.

\begin{tabular}{lll}
\hline Project name & PPP model & Project description \\
\hline Beijing Subway Olympic Line & BT & $\begin{array}{l}\text { First BT subway project in China. The project started construction on June 2003 and } \\
\text { completed on October 2008 (Yan and Cui, 2011). } \\
\text { The largest BT subway project at that moment, with total investment of approx. 3 billion } \\
\text { USD. The project started construction on December 2007 and completed on June 2011 (Yan } \\
\text { and Cui, 2011). } \\
\text { The project started construction on August 2004 and completed on September 2009, with } \\
\text { total investment of approx. 1.8 billion USD (Yan and Cui, 2011). }\end{array}$ \\
\hline
\end{tabular}

The application issue of PPP model has also been explored by researchers in the following infrastructure projects in China, e.g. Cross-sea Channel of the Bohai Strait (Zhang and Wang, 2013), Nanjing Yangtze NO. Three Bridge (Chen and Xu, 2006), Hong Kong Disneyland project (Ji et al., 2013), to name a few.

In contrast to the situation in China, 35\% and 34\% of the total PPP projects in U.K. were implemented in the education and health sector respectively between 2005 and 2009 (Gurgun and Touran, 2014). Considering the large population of China as well as the huge demands for better education and health services, governments shall try to test the PPP model in these two sectors in the future.

\section{Conclusions}

PPP has played a very important role in financing public projects in China since the first BOT project in 1980s. However, it also witnesses rises and falls in the last three decades. Learning from experience and lessons of these PPP projects will contribute to the improvement of the performance level in executing PPP projects in the future. Based on a critical review of 615 and 70 PPP publications in Chinese and International Journals in the last decade, respectively, the primary conclusions are obtained as the following:

- For Chinese Journals, case study is the most popular research method, followed by literature review and modelling. Whereas questionnaire survey is most frequently used by researchers in International Journals. In Chinese Journals, qualitative methods are more frequently adopted than quantitative methods, which is in contrast with the situation in International Journals. In recent years, more complicated modelling method (e.g. game theory) were increasingly adopted in PPP research.

- The research topics in PPP are diverse and dynamic in both Chinese and International Journals. Studies in Chinese Journals not only paid attention to summarize the application experience of PPP models in the context of China, but also had an eye on learning from the international experiences. Statistical analysis shows that PPP models and their application and Risk management topics are most frequently studied both in Chinese and International Journals. Research on the PPP models and their application topic focused on developing new PPP models, and application of various PPP models in particular sectors or project types.

There are two main themes in PPP Risk management field, i.e. identification \& evaluation of risk factors, and properly allocation of risk factors between the project participants. Although more than one fifth of the publications concentrated on this topic, there are still knowledge gaps, such as the quantitative evaluation of risk probability, risk impact and risk significance. Financing and economic issue research focused on the interrelated economic variables in evaluating PPP project to enable participants to make more scientific decisions, e.g. concession period, price of services or products, and government subsidy. Legal and procurement issue in these publications mainly involved the study on the legal system, procurement and contract. There are still many problems in the existing 
legal and procurement systems for PPP models in China, which need researchers to further study this issue and find solutions which are applicable to PPP model in Chinese construction industry. Future research directions in Government regulation and guarantee topic include the establishment of a central institution in administrating the development of PPP model in China, and the determination of optimization level of government guarantee in the best public interest based on various type of PPP models.

As an alternative approach to construct infrastructure project all over the world, PPP has several significant advantages comparing with other approaches, such as saving money, reducing financial burden of government, improving project quality and management efficiency, and so on. Although the history of PPP model in China is around 30 years, there is still a long way to go for the practitioners and researchers to know very well about this approach in China. Therefore, more holistic and pragmatic research on PPP management is still necessary considering the particular scenario and development status of Chinese construction industry.

This study has several main contributions to PPP body of knowledge. Firstly, the overall structure of PPP research field is comprehensively mapped in Chinese and International Journals in the context of China, the knowledge gaps are identified accordingly, and comparative study is also conducted between the two clusters of Journals. Secondly, the research findings will not only be valuable for Chinese researchers to embark on PPP research and enrich westerners understanding the PPP researches status in China, but also consolidate a basis to do comparative research with other sampling publications on PPP topic in the future. The research framework adopted in this study is simple but rigorous, and can be replicated to conduct similar research in the Construction Management field.

\section{Limitations and future research directions}

In order to improve the quality and accuracy of content analysis result, the research process, as illustrated in Section 2, mainly relies on physical works, e.g. reviewing PPP paper page after page to identify content, instead of alternative software process, such as Nivio. Therefore, during the research methods/topics identification process, subjective decision will be made to categorize specific method or topic when the dividing line is not clear and simple for some papers. This might be the first limitation of this study. However, such cases are rare since most of the research methods and topics can be easily classified. And the research team has been very careful to use the same standard in dealing with these cases. Secondly, this study may not include some good quality PPP publications in non-Class-A journals which is not in the scope of qualified journal list. However, it is believed by the research team that 615 high quality papers from Class-A journals in Chinese is sufficient in coverage and quantity to reflect PPP research status in the last decade in China, and to effectively achieve the research objectives outlined in Section 1 of this paper. Additionally, such good quality papers will be limited in numbers, since the classification for Class-A journals recommended by Peking University Library is well-known and generally acknowledged by academia in China. In fact, our main purpose is not to provide a full list of publications in Chinese Journals, but to solicit reliable information from authoritative knowledge sources as the basis for further statistical and comparison analysis. Finally, correlation analysis between the publishing year, research methods, research topics and findings, and nature of projects studied is not implemented. Some valuable data is missing when descriptive statistical analysis method is adopted exclusively in this study. Therefore, correlation analysis will be used to explore the dynamic change of PPP research development in both Journals in the future. 


\section{References}

Chan, A.P.C., Yeung, J.F.Y., Yu, C.C.P., Wang, S.Q., Ke, Y., 2011. Empirical study of risk assessment and allocation of public-private partnership projects in China. J. Manag. Eng. 136-148. http://dx.doi.org/10.1061/(ASCE) ME.1943-5479.0000049.

Chan, A.P.C., Lam, P.T.I., Chan, D.W.M., Cheung, E., Ke, Y.J., 2009. Drivers for adopting Public private partnerships - empirical comparison between China and Hong Kong special administrative region. J. Constr. Eng. Manag. 135 (11), 1115-1124.

Chan, A.P.C., Lam, P.T.I., Chan, D.W.M., Cheung, E., Ke, Y.J., 2010. Critical success factors for PPPs in infrastructure developments: Chinese perspective. J. Constr. Eng. Manag. 136 (5), 484-494.

Chang, Z., 2013. Public-private partnerships in China: a case of the Beijing No.4 Metro line. Transp. Policy 30, 153-160.

Chen, C., 2009. Can the pilot BOT Project provide a template for future projects? a case study of the Chengdu No. 6 Water Plant B Project. Int. J. Proj. Manag. 27, 573-583.

Chen, C., Doloi, H., 2008. BOT application in China: driving and impeding factors. Int. J. Proj. Manag. 26, 388-398.

Chen, C., Hubbard, M., 2012. Power relations and risk allocation in the governance of public private partnerships: a case study from China. Polic. Soc. 31, 39-49.

Chen, C., Messner, J.I., 2005. An investigation of Chinese BOT projects in water supply: a comparative perspective. Constr. Manag. Econ. 23 (9), 913-925.

Chen, D.Q., Zheng, S.S., 2011. PPP financing model and price mechanism of public renting house. Constr. Econ. 4, 12-16 (in Chinese).

Chen, T., Du, Z.C., Yao, D.L., 2011. Survey analysis on the importance of risk factors in PPP public projects. Shandong Soc. Sci. 11, 127-130 (in Chinese).

Chen, Y.M., Xu, Z.Y., 2006. Selection of financing model of city infrastructure on PPP perspective. Constr. Econ. 12, 30-33 (in Chinese).

Cheng, C., Wang, Z., 2009. Public private partnerships in China: making progress in a weak governance environment. The University of Nottingham

China Policy Institute (http://www.nottingham.ac.uk/cpi/documents/briefings/briefing-56chengchen-ppp.pdf (Feb. 6, 2015)).

Cheung, E., Chan, A.P.C., 2009. Is BOT the best financing model to procure infrastructure projects? A case study of the Hong Kong-Zhuhai-Macau Bridge. J. Prop. Invest. Financ. 27 (3), 290302.

Cheung, E., Chan, A.P.C., 2011. Risk factors of Public-Private Partnership projects in China: comparison between the water, power, and transportation sectors. J. Urban Plann. Dev. 137 (4), 409-415.

Cheung, E., Chan, A.P.C., Lam, P.T.I., Chan, D.W.M., Ke, Y.J., 2012. A comparative study of critical success factors for public private partnerships (PPP) between mainland China and the Hong Kong special administrative region. Facilities 30 (13/14), 647-666.

Chow, L.K., 2005. Incorporating fuzzy membership functions and gap analysis concept into performance evaluation of engineering consultants-Hong Kong study. Unpublished $\mathrm{PhD}$ thesis. The University of Hong Kong, Hong Kong.

Deng, X.P., Li, Q.M., Wang, W.X., Li, M., 2008. Literature review and application of risk allocation principle of PPP model. Constr. Econ. 9, 32-35 (in Chinese).

Du, Y.L., Wang, J.Y., 2013. Research on the proper allocation of rights of control in the projects under BT mode-a multi-case comparative study. Soft Sci. 27 (5), 56-61 (in Chinese).

Du, Y.L., Wang, Y., 2012. Study on the dynamic evolution of trust in PPP project. Constr. Econ. 8, 28-33 (in Chinese). 
Du, Y.L., Yin, Y.L., 2011. Review on the PPP project risk allocation. Constr. Econ. 4, 29-34 (in Chinese).

Fellows, R., Liu, A., 2008. Research Methods for Construction. third ed. Blackwell Science, Oxford, UK.

Gao, Y., Zhang, S.B., Feng, Z., 2014. Analysis of decision-making mechanism for operation period extension of public-private partnership projects under incomplete contracts. J. Manag. Sci. 2, 48-57 (in Chinese).

Guo, J., 2013. Research on traffic risk sharing strategy for Public-Private Partnerships highway infrastructure projects. Manag. Rev. 7, 11-18 (in Chinese).

Gurgun, A.P., Touran, A., 2014. Public-Private Partnership experience in the international arena: case of Turkey. J. Manag. Eng. http://dx.doi.org/10.1061/(ASCE)ME.1943-5479.0000213.

Hayllar, M.R., 2010. Public-Private Partnerships in Hong Kong: good governance- the essential missing ingredient? Aust. J. Public Adm. 69(S1), 99-119.

He, T., Zhao, G.J., 2011. Risk allocation in Public Private Partnerships based on stochastic cooperative game model. Syst. Eng. 29 (4), 88-92 (in Chinese).

$\mathrm{Hu}, \mathrm{Z}$., 2012. The decision model of the allocation of control rights in public-private partnerships projects. J. Xi'an Univ. Archit. Technol. 44 (1), 90-96 (in Chinese).

Hu, Z., Fan, X.Q., Dong, Q., 2012. Decision-making model of public-private partnerships projects' paradigm choice-based upon the SVM classified theory. J. Xi'an Univ. Archit. Technol. (Nat. Sci. Ed.) 44 (4), 568-571 (in Chinese).

Hu, Z., Liu, H., Jin, W.X., 2010. The computational model during franchise period of BOT projects regarding services sold to the public sector. Forecasting 29 (6), 43-47 (in Chinese).

Hu, Z., Liu, H., Jin, W.X., 2011. Study of the relationship between PPP project mode and risk allocation. China Civ. Eng. J. 44 (9), 139-146 (in Chinese).

Hu, Z., Liu, H., Liu, J.L., 2006. The government regulation system of U.K. PFI project. Constr. Econ. 10, 25-27 (in Chinese).

Ji, C., Cheng, L., Yuan, J.F., Li, Q.M., 2013. Evaluation on the value of public private partnership project by using fuzzy real option. J. Ind. Technol. Econ. 2, 49-55 (in Chinese).

Jin, N., Yang, N.D., Gao, J., 2007. The risk analysis of the PFI model in the project regional investment. Soft Sci. 21 (1), 10-13 (in Chinese).

Ke, Y.J., Wang, S.Q., Chan, A.P.C., 2008. Revelation of the channel Tunnel's failure to risk allocation in Public-Private Partnership Projects. China Civ. Eng. J. 41 (12), 97-102 (in Chinese).

Ke, Y.J., Wang, S.Q., Chan, A.P.C., 2010a. Risk allocation in Public-Private Partnership infrastructure projects: comparative study. J. Infrastruct. Syst. 16 (4), 343-351.

Ke, Y.J., Wang, S.Q., Chan, A.P.C., Cheung, E., 2009. Research trend of Public-Private Partnership in construction journals. J. Constr. Eng. Manag. 135 (10), 1076-1086.

Ke, Y.J., Wang, S.Q., Chan, A.P.C., Cheung, E., 2011. Understanding the risks in China's PPP projects: ranking of their probability and consequence. engineering. Constr. Archit. Manag. 18 (5), 481-496.

Ke, Y.J., Wang, S.Q., Chan, A.P.C., Lam, P.T.I., 2010b. Preferred risk allocation in China's publicprivate partnership (PPP) projects. Int. J. Proj. Manag. 28, 482-492.

Kolbe, R.H., Burnett, M.S., 1991. Content analysis research: an examination of applications with directives for improving research reliability and objectivity. J. Consum. Res. 18 (2), 243-250.

Kuang, Y., Lian, D.W., Zhao, X.F., 2008. Study on computing subsidization and service level in PPP financing of urban rail transit project. China Eng. Sci. 10 (6), 87-90 (in Chinese).

Le, Y., Shan, M., Chan, A.P.C., Hu, Y., 2014. Overview of corruption research in construction. J. Manag. Eng. http://dx.doi.org/10.1061/(ASCE)ME.1943-5479.0000300, 02514001-1-7.

Lee, S., 2010. Development of Public Private Partnership (PPP) projects in the Chinese water sector. Water Resour. Manag. 24, 1925-1945. 
Li, B., Akintoye, A., Edwards, P.J., Hardcastle, C., 2005. Critical success factors for PPP/PFI projects in the UK construction industry. Constr. Manag. Econ. 23 (5), 459-471.

Li, J., Zou, X.W., 2008. Questionnaire survey on the PPP risk perspective of contractors. Constr. Econ. 8, 31-34 (in Chinese).

Li, L.H., 2012. Urban renewal partnerships-is there really room for participation from individual owners? a case study of Hong Kong. J. Housing Built Environ. 27, 517-526.

Li, Q.M., Xiong, W., Yuan, J.F., 2010. The price adjustment mechanism of PPP project based on satisfaction of participants. J. Southeast Univ. (Philos. Soc. Sci.) 12 (1), 16-20 (in Chinese).

Liu, B., Chen, R.D., 2005. Theory of C-BOT system: a new construction of the theory of urbanization development. China Soft Sci. 4, 138-146 (in Chinese).

Liu, J.C., Cheah, C.Y.J., 2009. Real option application in PPP/PFI project negotiation. Constr. Manag. Econ. 27 (4), 331-342.

Liu, N., Dai, D.S., Wu, H.X., 2010. Review on real option for BOT Projects. J. Dalian Univ. Technol. (Soc. Sci.) 31 (3), 34-39 (in Chinese).

Liu, T.T., Wilkinson, S., 2014. Large-scale public venue development and the application of PublicPrivate Partnerships (PPPs). Int. J. Proj. Manag. 32, 88-100.

Liu, W., Lv, J.N., Zou, Q., 2012. Decision-making model on concession period for traffic BOT project under uncertainty. Syst. Eng. 30 (12), 51-56 (in Chinese).

Marshall, C., Rossman, G.B., 1998. Designing Qualitative Research. Sage, Thousand Oaks, CA.

Ministry of Finance (MoF) China, 2014a. Experience from Asian Development Bank in applying PPP model and Suggestions. China State Financ. 9, 18-19 (in Chinese).

Ministry of Finance (MoF) China, 2014b. The critical success factors in implementing PPP project based on international experience. China State Financ. 15, 44-45 (in Chinese).

Nanfangweekend, 2015. PPP regulation and development. http://www.infzm.com/content/109245 (May 2, 2015).

Ng, S.T., Wong, J.M.W., Wong, K.K.W., 2013. A public private people partnerships (P4) process framework for infrastructure development in Hong Kong. Cities 31, 370-381.

Phang, S.Y., 2007. Urban rail transit PPPs: survey and risk assessment of recent strategies. Transp. Policy 14, 214-231.

Public-Private Infrastructure Advisory Facility, 2007. Public Private Partnership Units: Lessons for their Design and Use in Infrastructure. World Bank, Washington, DC.

Public-Private Infrastructure Advisory Facility, 2012. Developing a public-private partnership framework: Policies and PPP units. http://www.ppiaf.org/sites/ppiaf.org/files/documents/Note-Four-Developing-aPPPFramework.pdf (Feb. 6, 2015).

Qi, X., Ke, Y.J., Wang, S.Q., 2009. Case study on risk factors of PPP project in China. China Soft Scienc. 5, 107-113 (in Chinese).

Shen, L.Y., Platten, A., Deng, X.P., 2006. Role of public private partnerships to manage risks in public sector projects in Hong Kong. Int. J. Proj. Manag. 24, 587-594.

Song, J., 2012. Study on the project decision framework of offshore railway PPP model. Constr. Econ. 6, 23-26 (in Chinese).

Song, J.B., Dang, W., Sun, Y., 2013. Decision modes for flexible concession term in public infrastructure BOT projects - a multi-case study on foreign typical Projects. China Civ. Eng. J. 46 (4), 142-150 (in Chinese).

Song, J.B., Wang, D.B., Song, D.R., 2010. A decision model of concession period for build-operatetransfer projects of wastewater treatment based on Monte Carlo Simulation. J. Ind. Eng./Eng. Manag. 24 (4), 93-99 (in Chinese).

Sun, H., Ye, X.X., 2013. Study of the allocation of residual control rights in the Public-Private Partnership under incomplete contracts. J. Syst. Eng. 28 (2), 227-233 (in Chinese). 
Sun, H., Shen, K.K., Fan, Z.Q., 2012. Analysis of factors influencing PPP project performance based on SEM. J. Tianjin Univ. (Soc. Sci.) 14 (6), 513-519 (in Chinese).

Sun, H., Sun, X.P., Fan, Z.Q., 2011a. Comparative analysis and inspiration of renegotiation issue in Public-Private Partnership projects. J. Tianjing Univ. (Soc. Sci.) 13 (4), 294-297 (in Chinese).

Sun, Y.F., Zhang, L.Y., Han, H.F., 2011b. The accounting problems of government guarantees in PPP public projects. Theory Pract. Financ. Econ. 32, 62-66 (in Chinese).

Tan, W., Tan, D.Q., 2008. Study on the government guarantee in BOT project under heterogeneous beliefs. Stat. Decis. 14, 54-56 (in Chinese).

Tang, L.Y.N., 2011. Effective and efficient briefing in Public Private Partnership projects in the construction industry. Unpublished PhD thesis, The Hong Kong Polytechnic University, Hong Kong, 2011.

Tang, L.Y.N., Shen, Q.P., Skitmore, M., Cheng, E.W.L., 2013. Ranked critical factors in PPP briefings. J. Manag. Eng. 29 (2), 164-171.

Taylor, J.E., Jaselskis, E.J., 2010. Introduction to the special issue on research methodologies in construction engineering and management. J. Constr. Eng. Manag. 1-2 http://dx.doi.org/10.1061/(ASCE)CO.1943-7862.0000141.

Tserng, H.P., Russell, J.S., Hsu, C.W., Lin, C., 2012. Analyzing the role of national PPP units in promoting PPPs: using new institutional economics and a case study. J. Constr. Eng. Manag. 138 (2), 242-249.

Wang, B.A., 2014a. Actively promote the application of PPP model to improve the public service level. China State Financ. 9, 11-13 (in Chinese).

Wang, C.C., 2014b. Legal documentation system, core contract conditions and public interest. China State Financ. 9, 29-31 (in Chinese).

Wang, D.B., Song, J.B., Dai, D.S., Han, S.D., 2009. Review on decision method of concession period for build operate transfer projects. Forecasting 28 (3), 1-8 (in Chinese).

Wang, D.B., Song, J.B., Dai, D.S., Li., Z., 2010. A methodology for determining the concession period of BOT highway projects under uncertainty of revenue. Forecasting 29 (2), 58-63 (in Chinese).

Wang, D.P., Wang, W., 2013. Literature review on PPP model selection of infrastructure project. Proj. Manag. Technol. 11 (12), 39-45 (in Chinese).

Wang, W.X., Li, Q.M., 2008. Early warning of risk for transportation infrastructure projects under a PPP model. J. Chongqing Jianzhu Univ. 30 (5), 90-94 (in Chinese).

Wang, X.Q., Yu, G., Bing, X.G., 2007. The analysis of risk allocation on the PPP financing model. Soft Sci. 21 (6), 39-42 (in Chinese).

Wang, Y.L., Liu, J.C., Lai, J.Y., 2013. Risk allocation game theory model based on risk attitude. Constr. Econ. 12, 44-47 (in Chinese).

Wang, Z.A., Deng, X.P., Li, Q.M., Yang, S., Yuan, J.F., 2008. Application of PPP model in city development. Constr. Econ. 9, 36-39 (in Chinese).

Willoughby, C., 2013. How much can public private partnership really do for urban transport in developing countries? Res. Transp. Econ. 40, 34-55.

World Bank, 2013. Private participation in infrastructure database. http://ppi.worldbank.org/explore/Report.aspx?mode=1 (Feb. 6, 2015).

Xu, Y.L., Yang, Y.F., Chan, A.P.C., Yeung, J.F.Y., Cheng, H., 2011. Identification and allocation of risks associated with PPP water projects in China. Int. J. Strateg. Prop. Manag. 15 (3), 275294.

Xu, Y.L., Chan, A.P.C., Yeung, J.F.Y., 2010. Developing a fuzzy risk allocation model for PPP projects in China. J. Constr. Eng. Manag. 136 (8), 894-903.

Yan, L., Cui, J., 2011. Multi-case study of PPP model selection of city subway project. Sci. Technol. Prog. Technol. 28 (13), 110-115 (in Chinese). 
Yan, P.S., Wang, X.J., 2009. The mechanism design for franchise bidding in traffic BOT Project. Chin. J. Manag. Sci. 17 (4), 97-102 (in Chinese).

Ye, S.D., 2012. A study on the subsidizing systems of urban railway transport projects under BOT model. J. Beijing Jiaotong Univ. (Soc. Sci. Ed.) 11 (4), 22-29 (in Chinese).

Ye, X.S., Yang, J.P., 2012. PPP project price setting based on multi-objective planning model. Stat. Decis. 6, 74-76 (in Chinese).

Ye, X.X., Sun, H., Fan, Z.Q., 2011. PPP legislation in South Korea and its implication for China. Int. Econ. Coop. 2, 52-55 (in Chinese).

Yeung, J.F.Y., 2007. Developing a partnering performance index for construction projects - a fuzzy set theory approach. Unpublished PhD thesis. The Hong Kong Polytechnic University, Hong Kong.

Yi, W., Chan, A.P.C., 2014. Critical review of labor productivity research in construction journals. J. Manag. Eng. 30 (2), 214-225.

Yin, Y.L., Jiang, J.B., 2011. Study of control on investment upfront in construction in BT mode. J. Beijing Inst. Technol. (Soc. Sci. Ed.) 13 (2), 1-5 (in Chinese).

Yin, Y.L., Yin, X.L., 2013. Study on risk share in PPP construction mode of Beijing Metro line. Railw. Transp. Econ. 35 (10), 6-11 (in Chinese).

Yuan, J.F., Skibniewski, M.J., Li, Q.M., Shan, J., 2010a. The driving factors of China's PublicPrivate Partnership projects in metropolitan transportation systems: public sector's viewpoint. J. Civ. Eng. Manag. 16 (1), 5-18.

Yuan, J.F., Skibniewski, M.J., Li, Q.M., Zheng, L., 2010b. Performance objectives selection model in Public-Private Partnership projects based on the perspective of stakeholders. J. Manag. Eng. 26 (2), 89-104.

Yuan, J.F., Deng, X.P., Li, Q.M., Wang, W.X., 2007. PPP legislation and its application in China. Constr. Econ. 3, 95-98 (in Chinese).

Yuan, J.F., Guang, M., Wang, X.X., Li, Q.M., Skibniewski, M.J., 2012. Quantitative SWOT analysis of public housing delivery by Public-Private Partnerships in China based on the perspective of the public sector. J. Manag. Eng. 28 (4), 407-420.

Zhang, J.S., Wang, G.B., 2012. Decision-making model and analysis on concession period for BOT projects by stages. J. Tongji Univ. (Nat. Sci.) 40 (9), 1434-1438 (in Chinese). 